Japan. J. MedSci.. Biol., 29, 11-24, 1976

\title{
TEMPORAL ANALYSIS OF CELLULAR CYTOTOXICITY AND HUMORAL FACTORS DURING PROGRESSION AND REGRESSION OF ROUS SARCOMAS IN JAPANESE QUAILS
}

\author{
Masanori HAYAMI, Masahiro ITO, Yasuhiro YOSHIKAWA \\ and KAZUYA YAMANOUCHI
}

Department of Measles Virus, National Institute of Health, Musashi-Murayama, Tokyo 190-12, Japan

(Received: November 12, 1975)

\begin{abstract}
SUMMARY : Temporal appearance of cellular cytotoxicity and humoral activities including blocking and arming activities during the entire course of Rous sarcoma development in Japanese quails was examined by microcytotoxicity assay with comparison of animals bearing regressing tumors induced by a moderate dose of virus (regressors) and animals bearing growing tumors induced by a large dose of virus (progressors).

Cellular cytotoxicity of the spleen cells in regressors was detected in a biphasic pattern; the first phase being observed as early as 3-5 days post inoculation (p.i.), followed by an eclipse period between 7-10 days p.i. which was the time of active tumor growth, and the second phase occurring after 12 days p.i. when the tumor had attained the maximum size. In progressors, only the first phase was observed. Instead, a stimulatory effect of the spleen cells on growth of target cells was noticed.

Arming activity which confers cytotoxic activity on the normal spleen cells was demonstrated in the sera of regressors in the similar biphasic pattern as the cellular cytotoxicity; the early activity being present at 3 days p.i., and the late one after 19 days p.i. The former was detected by pre-incubation of serum with effector cells in microcytotoxicity assay and the latter by pre-incubation with target cells. In progressors, only the early arming activity which reacts with effector cells was demonstrated.

Blocking activity which abrogates cellular cytotoxicity was demonstrated in both regressors and progressors but in different patterns of appearance, that is, blocking activity in regressors was only transiently demonstrated only by pre-incubation with effector cells at the time of maximum tumor growth, while the activity in progressors seemed to persist after the tumor reached the maximum size. Since the earlier activity was found to be effective at effector cell level, and the later one at both effector and target cell levels, participation of blocking factors of different types in progressors was also suggested.
\end{abstract}

\section{INTRODUCTION}

Evidence showing involvement of both cell-mediated and humoral immunities in the outcome of primary tumors has accumulated. The cell-mediated immunity has been demonstrated mainly by the presence of lymphocytes cytotoxic to tumor cells in an in vitro system such as microcytotoxicity assay or the

速水正憲・伊藤正博・吉川泰弘・山内一也（国立予防衛生研究所麻疹ウィルス部） 
${ }^{51} \mathrm{Cr}$-release test. By these in vitro systems, humoral factors including blocking, unblocking or arming factor have successfully been demonstrated in several primary tumors of experimental animals (Hellström and Hellström, 1973; Hellström and Hellström, 1970; Pollack et al., 1972; Hayami et al., 1973).

Japanese quails bearing Rous sarcoma virus (RSV)-induced primary tumors have been employed to analyze the relationships of such humoral factors and cytotoxic lymphocytes in regression of the primary tumors. The previous experiments were conducted with the spleen cells and sera harvested 3-5 weeks after virus inoculation with particular emphasis on the immune state of the hosts at the stage when most of the tumors completely regressed. As a result, cytotoxic spleen cells were demonstrated in the quails whose tumors regressed (regressors), but not in those whose tumors progressed (progressors) (Hayami et al., 1972). Blocking factors were more frequently demonstrated in the sera of the progressors at higher activity than those of the regressors. It was suggested that these blocking factors might consist of antigen-antibody complex or antigen; the former being involved in both the progressors and regressors and the latter in the progressors whose humoral antibody response was partially suppressed by neonatal bursectomy. Arming factor which confers cytotoxic activity on the normal spleen cells was detected mainly in the sera of the regressors (Hayami et al., 1973; Hayami et al., 1974).

In the present study, time sequential examinations were made on the appearance of cytotoxic spleen cells and that of blocking and arming factors in the sera during tumorigenesis.

\section{Materials And Methods}

Animals: Japanese quails (Coturnix coturnix Japonica) were obtained from a closed colony in the Nippon Institute for Biological Science, Tokyo, and used at the age of 4 weeks.

Virus: A stock of the Schmidt-Ruppin strain of Rous sarcoma virus (SR-RSV) was prepared as previously described (Yamanouchi et al., 1968); its titer being $10^{5.25} \mathrm{FFU} / \mathrm{ml}$ in chicken embryo cells.

Experimental design: Four groups of quails each consisting of approximately 40-50 animals were used. As it had consistently been demonstrated that inoculation of $100 \mathrm{FFU}$ of virus resulted in tumors of which more than $90 \%$ regressed, and that inoculation of over 1,000 FFU resulted in tumors of which the majority were progressive (Yamanouchi et al., 1968), two groups were inoculated with 100 FFU into the wing web and the other two with 5,000 FFU; the former being considered to represent regressors and the latter to represent progressors.

At 2 to 3-day intervals, the tumor sizes of all surviving quails were measured. At each time, three quails were sacrificed; their spleens being tested for cytotoxic activity and the sera being stored at $-20 \mathrm{C}$ until tested for blocking and arming activities.

Because of a relatively large number, serum samples were divided into three 
groups consisting of one serum from each sampling. The sera of one group were tested for blocking and arming activities by using the same sample of effector cells in order to minimize the variation in results caused by different samples of effector cells. Mean values of activities for the three sera at each sampling were calculated from the results of three separate tests.

Detection of cytotoxic lymphoid cells: The microcytotoxicity test developed by Takasugi and Klein (1970) was employed. Target cells and spleen cells were prepared as previously described (Hayami et al., 1973). The in vitro passaged quail tumor cells were suspended in Eagle's F-12 medium containing $15 \%$ fetal calf serum and $40 \%$ conditioned medium (i.e., medium in which quail embryo cells had been cultured for 3 days). As a target cell, they were seeded in Microtest plates II (Falcon Plastics, No. 3040) at a dose of 100 cells/well. After incubation at $39 \mathrm{C}$ for $3 \mathrm{hr}$ in a humidified $\mathrm{CO}_{2}$ incubator, the medium was decanted and spleen cells of either virus-inoculated or normal quails were added to the target cells at a ratio of 100 spleen cells to one target cell (actually $10^{4}$ spleen cells to $10^{2}$ target cells).

The plates were further incubated for 40 to $42 \mathrm{hr}$ and stained with Giemsa; the surviving cells were counted.

Lymphocyte cytotoxicity was expressed as per-cent destruction by the following formula:

Per-cent destruction $=($ mean number of surviving target cells with normal spleen cells-mean number of surviving target cells with immune spleen cells) $\times$ $100 /$ mean number of surviving target cells with normal spleen cells.

Statistical significance was calculated by Student's t-test.

Assays for blocking and arming activities: Test sera were diluted in Eagle's medium and inactivated at $56 \mathrm{C}$ for $30 \mathrm{~min}$. Blocking and arming activities were assayed in three ways as previously described (Hayami et al., 1974):

Method 1 (pre-treatment of spleen cells) Spleen cells from the virus-inoculated quails were incubated with an equal volume of test serum (diluted 1:4) for $45 \mathrm{~min}$ at $39 \mathrm{C}$. After being washed three times with Eagle's medium, $10 \mu$ of the spleen cell suspension containing $10^{4}$ cells were added to each well.

Method 2 (pre-treatment of target cells) Prior to the addition of spleen cells, target cells were incubated with $10 \mu \mathrm{l}$ of test serum (diluted $1: 4$ ) for $45 \mathrm{~min}$ at $39 \mathrm{C}$ and then washed three times with Eagle's medium.

Method 3 (standard procedure without pre-treatment) Five $\mu$ l of test serum (diluted $1: 2)$ and $5 \mu 1$ of the spleen cell suspension $\left(10^{4}\right.$ cells) were added to the target cells at the same time and the mixture was left unwashed during the entire test.

To assay for blocking activity, the spleen cells were obtained from three quails 1-2 weeks after tumor regression, pooled, and employed as indicator effector cells, while the normal spleen cells pooled from three uninoculated quails were employed as control effector cells.

To assay for arming activity, the normal spleen cells, which served as the control effector cell in the assay for blocking activity, were employed as indicator cells. Thus, both blocking and arming activities of one serum sample were assayed in a single experiment. 
The two activities were calculated as follows:

Per-cent blocking $=$ (per-cent destruction with normal serum-per-cent destruction with test serum $) \times 100 /$ per-cent destruction with normal serum.

Per-cent arming $=$ (mean number of surviving target cells with normal spleen cells in the presence of normal serum-mean number of surviving target cells with normal spleen cells in the presence of immune serum $) \times 100 /$ mean number of surviving target cells with normal spleen cells in the presence of normal serum.

Statistical significance of per-cent arming activity was calculated by Student's t-test. Fifty per-cent or higher blocking was considered as a positive reaction as described previously (Hayami et al., 1973).

\section{RESULTS}

\section{Temporal Appearance of Cytotoxic Spleen Cells, Blocking Factors, and Arming Factor in Regressors}

As similar results were obtained in two separate experiments, those of one experiment are shown in Table I and Figs. 1-3. As shown in Fig. 1, tumors became detectable at 7 days, reached maximum in size at 12 days, and regressed almost completely by 28 days post inoculation (p.i.). Results of microcytotoxicity assays performed for detection of cellular cytotoxic activity, and humoral blocking and arming activities are summarized in Table I. The temporal relationships between

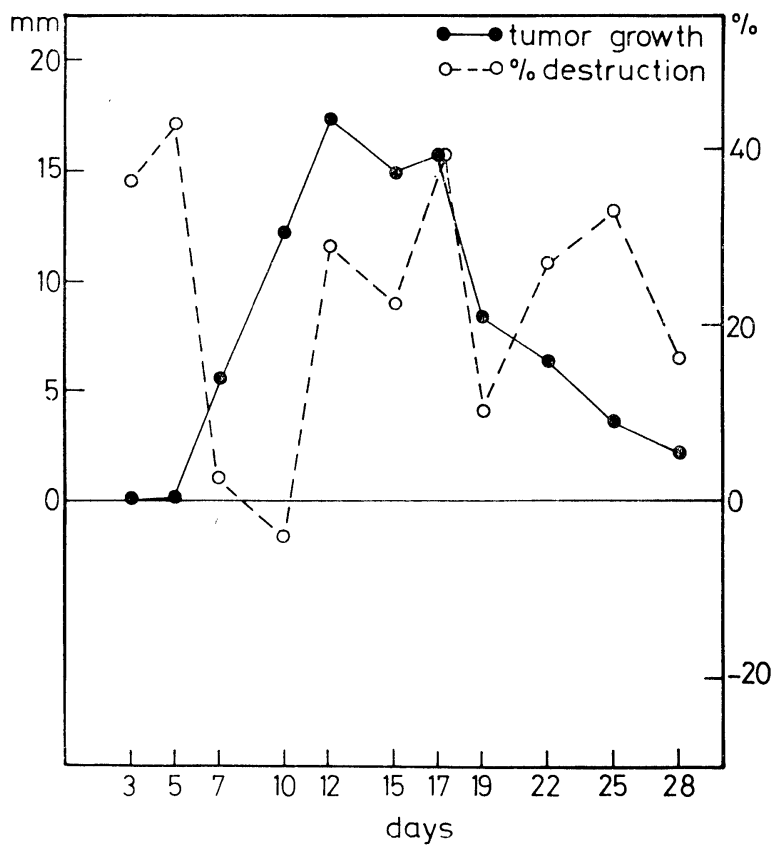

Fig. 1. Tumor growth and cell-mediated destruction in regressors. 


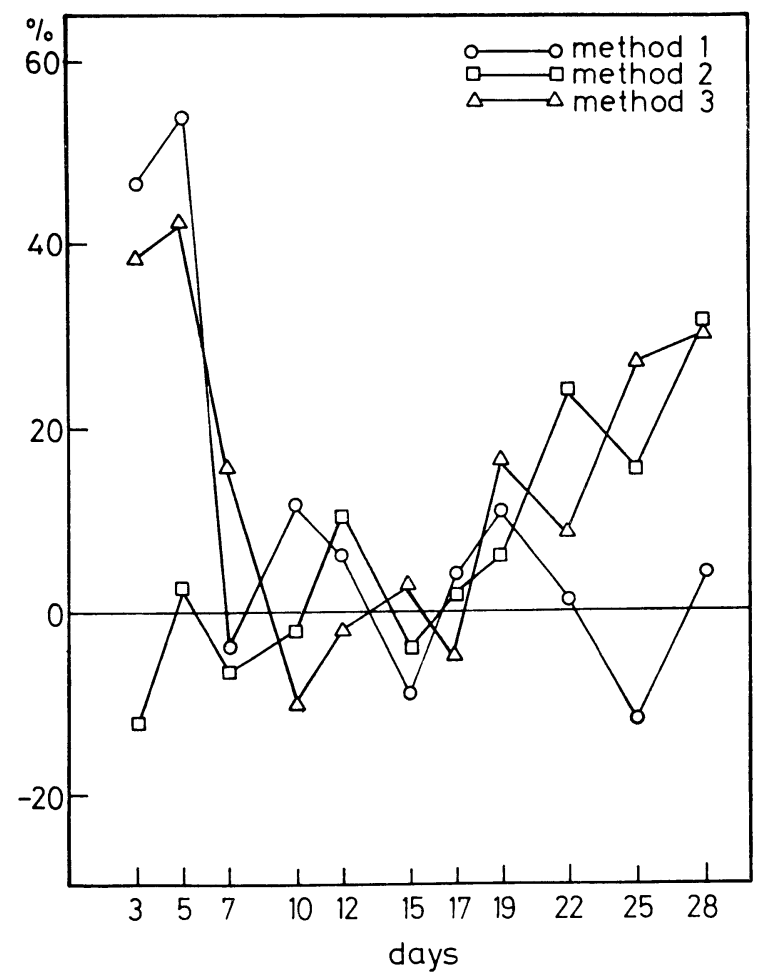

Fig. 2. Arming activity of regressors detected by three methods.

Methed 1: Pre-treatment of spleen cells.

Method 2: Pre-treatment of target cells.

Method 3: Standard procedure without pre-treatment.

these cellular and humoral activities are also depicted in Figs. 1-3 by plotting the mean values in each sampling group to exhibit a general tendency.

Cellular cytotoxicity was detected on a significant level 3-5 days p.i. when the tumors were not palpable as yet. At 7-10 days the cellular cytotoxicity declined and it was below the significant level; four of the six birds showing minus per-cent cytotoxicity. At 12 days or later, the cellular cytotoxic activity tended to re-appear, and remained on a significantly high level after tumor regression about 22-28 days p.i.

Arming activity was similarly detected at an early stage of 3-5 days p.i. During a period of 7-17 days, arming activity remained on a low level except for a few birds which showed a significant activity. After 19 days an increase in arming activity was noted, and significantly high arming activity was detected at 28 days. It is noteworthy that all the early arming activity at 3-7 days was detected by both methods 1 and 3 , while the late arming activity was detected exclusively by methods 2 and 3 . Thus the early arming activity was considered to be effective on the effector-cell level, and the late one on the target-cell level.

Blocking activity was demonstrated in a small number of birds $7-15$ days p.i. 
TABLE I

Temporal appearance of cytotoxic spleen cells, arming factor, and blocking factor in regressors

\begin{tabular}{|c|c|c|c|c|c|c|c|c|}
\hline \multirow{2}{*}{$\begin{array}{l}\text { Days } \\
\text { p.i. }\end{array}$} & \multirow{2}{*}{$\begin{array}{c}\text { Quail } \\
\text { No. }\end{array}$} & \multirow[t]{2}{*}{$\%$ Destruction } & \multicolumn{3}{|c|}{$\%$ Arming by method 1} & \multicolumn{3}{|c|}{$\%$ Blocking by method ${ }^{1}$} \\
\hline & & & 1 & 2 & 3 & 1 & 2 & 3 \\
\hline \multirow[t]{3}{*}{3} & $16-1$ & 20.2 & $30.3^{* * * 2}$ & -8.2 & 22.7 & -1.2 & 6.3 & -9.2 \\
\hline & $16-2$ & $40.4 * * *$ & $58.6^{* * *}$ & -28.3 & $50.2 * * *$ & -20.8 & -13.9 & 11.2 \\
\hline & $16-3$ & $48.5 * * *$ & $50.4 * * *$ & 0.2 & $42.1 * * *$ & 8.0 & 14.4 & 19.5 \\
\hline \multirow[t]{3}{*}{5} & $16-4$ & $45.1 * * *$ & $73.5^{* * *}$ & -19.1 & $44.8 * * *$ & 0.6 & -2.9 & -3.2 \\
\hline & $16-5$ & 21.7 & $31.2^{* *}$ & 5.1 & 20.2 & -22.2 & 16.0 & -27.4 \\
\hline & $16-6$ & $63.3^{* * *}$ & $55.7 * * *$ & 23.3 & $62.3^{* * *}$ & 18.5 & -27.7 & 15.1 \\
\hline \multirow[t]{3}{*}{7} & $16-7$ & -3.1 & 10.3 & 7.7 & 9.3 & 21.1 & 19.4 & -34.5 \\
\hline & $16-9$ & 17.8 & -12.1 & -13.3 & 7.9 & 41.4 & -3.6 & $54.8^{\circ 3}$ \\
\hline & $16-10$ & -5.7 & -10.5 & -15.4 & $29.4^{* *}$ & 19.2 & -1.5 & -32.6 \\
\hline \multirow[t]{3}{*}{10} & $16-11$ & -13.4 & -4.2 & -25.2 & 15.0 & 36.4 & -10.0 & 15.3 \\
\hline & $16-13$ & 22.6 & $36.2^{* *}$ & 15.1 & -20.5 & $76.4^{\circ}$ & 26.3 & $55.4^{\circ}$ \\
\hline & $16-14$ & -18.5 & 1.6 & 3.5 & $-25.1^{* *}$ & 41.7 & -14.4 & 20.8 \\
\hline \multirow[t]{3}{*}{12} & $16-15$ & 20.2 & $25.1 * *$ & 1.5 & -11.6 & 27.3 & -16.5 & 28.3 \\
\hline & $16-16$ & 19.5 & -4.3 & $29.2^{* *}$ & 17.2 & 27.0 & 13.5 & 27.1 \\
\hline & $16-17$ & $48.7 * * *$ & -3.5 & 0.5 & -12.7 & $56.0^{\circ}$ & -15.8 & $56.5^{\circ}$ \\
\hline \multirow[t]{3}{*}{15} & $16-18$ & 14.3 & -17.7 & -12.6 & -5.3 & $53.5^{\circ}$ & 26.2 & $53.3^{\circ}$ \\
\hline & $16-19$ & 6.4 & 15.4 & -20.1 & -13.8 & 13.3 & -14.4 & 20.8 \\
\hline & $16-20$ & $46.8^{* * *}$ & -25.8 & 20.6 & $27.4^{* *}$ & 21.8 & -6.3 & 13.1 \\
\hline \multirow[t]{3}{*}{17} & $16-22$ & $51.4 * * *$ & 10.5 & 8.3 & 1.9 & -12.3 & 1.7 & 18.6 \\
\hline & $16-24$ & 21.4 & -14.8 & -16.8 & -23.5 & 12.8 & 30.8 & 24.5 \\
\hline & $16-25$ & $45.9 * * *$ & 16.4 & 14.4 & 7.0 & 18.5 & 25.8 & -6.3 \\
\hline \multirow[t]{3}{*}{19} & $16-27$ & 26.1 & 18.6 & -17.7 & 23.6 & -2.7 & -9.2 & 37.9 \\
\hline & $16-28$ & 17.2 & -12.9 & 22.0 & -7.1 & 37.4 & 30.9 & 8.6 \\
\hline & $16-29$ & -13.6 & $27.9 * *$ & 13.5 & $32.7 * * *$ & 28.3 & 21.8 & 47.3 \\
\hline \multirow[t]{3}{*}{22} & $16-30$ & $43.1 * * *$ & -1.7 & 21.8 & 6.2 & -4.8 & 16.6 & 9.4 \\
\hline & $16-31$ & 13.5 & 17.1 & $37.6^{* * *}$ & $24.8^{*}$ & 14.0 & 34.4 & 21.2 \\
\hline & $16-34$ & $25.3^{* *}$ & -13.8 & 9.9 & -6.3 & -16.4 & 4.4 & 39.1 \\
\hline \multirow[t]{3}{*}{25} & $16-36$ & $28.9 *$ & 8.2 & $39.7 * * *$ & 23.9 & 18.1 & 1.2 & 26.3 \\
\hline & $16-37$ & $56.6 * * *$ & -8.3 & 11.9 & 7.4 & -10.8 & -15.4 & -2.9 \\
\hline & $16-38$ & 12.2 & $-36.9 * * *$ & -5.0 & $51.0 * * *$ & -26.2 & 29.9 & -18.4 \\
\hline \multirow[t]{3}{*}{28} & $16-39$ & 10.8 & -12.0 & 15.8 & 14.5 & 17.5 & 27.0 & -7.6 \\
\hline & $16-40$ & $27.7 * *$ & 19.0 & $32.1 * *$ & $45.1 * * *$ & -14.9 & -4.7 & 24.5 \\
\hline & $16-41$ & 11.3 & 5.1 & $46.9 * * *$ & $31.6^{* *}$ & 3.3 & 14.0 & 10.7 \\
\hline
\end{tabular}

1 Method 1: Pre-treatment of spleen cells

Method 2: Pre-treatment of target cells

Method 3: Standard procedure without pre-treatment

2 Statistically significant at probabilities:

* $\mathrm{p}<0.05,{ }^{* *} \mathrm{p}<0.01{ }^{* * *} \mathrm{p}<0.001$

3 Significant blocking at levels higher than $50 \%$. 


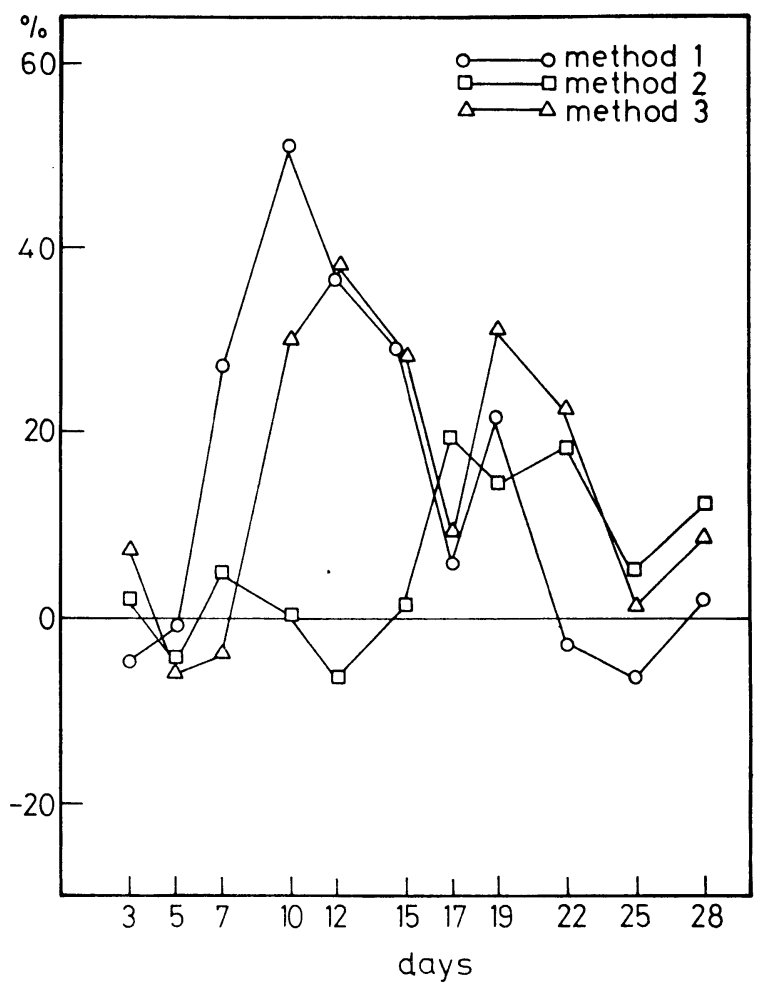

Fig. 3. Blocking activity of regressors detected by three methods. See footnotes of Fig. 2.

almost in parallel to tumor growth. The fact that the blocking activity was detected by methods 1 and 3 but not by method 2 indicated the effectiveness of this activity on the effector-cell level.

\section{Temporal Appearance of Cytotoxic Spleen Cells, Blocking Factors, and Arming Factor in Progressors}

The results of one of the duplicate experiments are shown in Table II and Figs. 4-6 in the same way as for the regressors. As shown in Fig. 4, the initial course of tumor development followed the same pattern as that of regressors; tumors became detectable at 5-7 days and reached the maximum size at 12-14 days. After 14 days, however, most of the tumors in progressors maintained a large size without showing any sign of regression. A few (8.6\%) of the tumors did regress 17 days p.i. and these animals were excluded from the evaluation.

Cellular cytotoxicity was detected at 3-5 days as in the case of regressors (Fig. 4). However, it disappeared 7 days p.i., and did not re-appear during the remaining experimental period. During the period of 10-21 days p.i., a tendency toward minus per-cent destruction was observed suggesting a stimulating effect of 


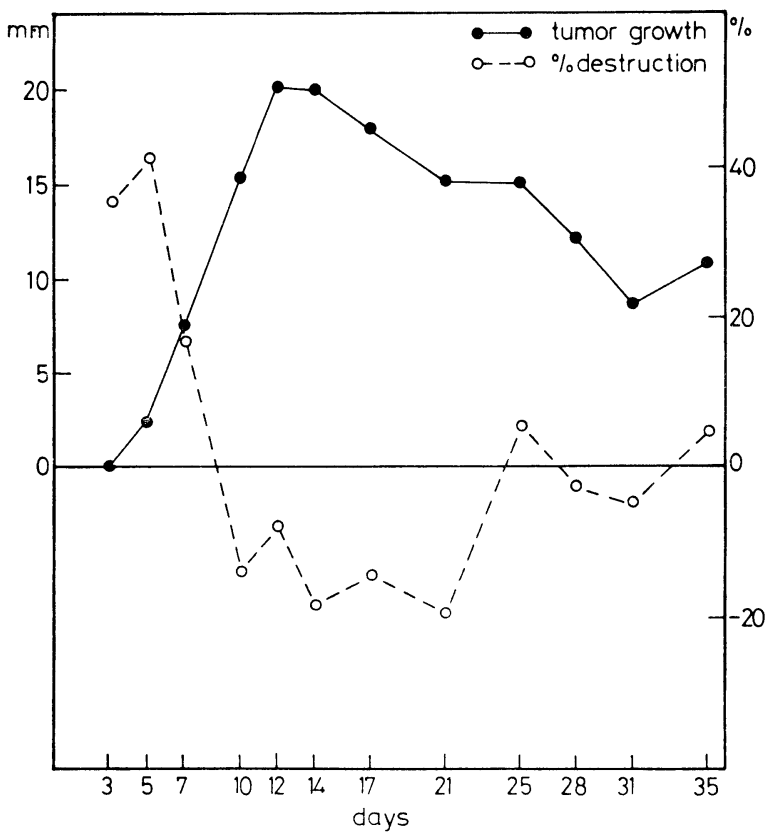

Fig. 4. Tumor growth and cell-mediated destruction in progressors.

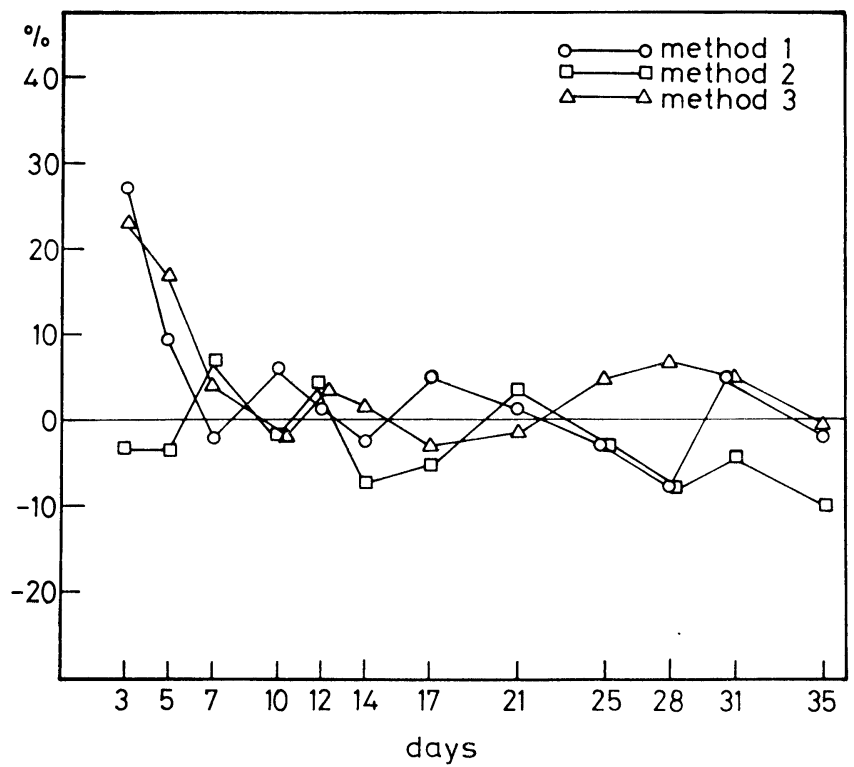

Fig. 5. Arming activity of progressors detected by three methods. See footnotes of Fig. 2. 
TABLE II

Temporal appearance of cytotoxic spleen cells, arming factor, and blocking factor in progressors

\begin{tabular}{|c|c|c|c|c|c|c|c|c|}
\hline \multirow{2}{*}{$\begin{array}{l}\text { Days } \\
\text { p.i. }\end{array}$} & \multirow{2}{*}{$\begin{array}{l}\text { Quail } \\
\text { No. }\end{array}$} & \multirow{2}{*}{$\%$ Destruction } & \multicolumn{3}{|c|}{$\%$ Arming by method ${ }^{1}$} & \multicolumn{3}{|c|}{$\%$ Blocking by method ${ }^{1}$} \\
\hline & & & 1 & 2 & 3 & 1 & 2 & 3 \\
\hline \multirow[t]{3}{*}{3} & $17-1$ & $37.6 * * * 2$ & $43.7 * * *$ & 13.4 & $37.6 * * *$ & -4.0 & 16.0 & -8.2 \\
\hline & $17-2$ & 16.6 & 1.4 & -12.4 & -0.9 & 17.2 & 20.2 & 11.8 \\
\hline & $17-4$ & $52.3^{* * *}$ & $36.4^{* * *}$ & -9.9 & $32.5^{* *}$ & 11.5 & -8.5 & -16.5 \\
\hline \multirow[t]{3}{*}{5} & $17-5$ & $22.2^{*}$ & -8.3 & -18.1 & 0.8 & 8.7 & -14.3 & 3.8 \\
\hline & $17-6$ & $53.1^{* * *}$ & 10.7 & 9.4 & 21.0 & -14.2 & -8.9 & -20.2 \\
\hline & $17-7$ & $48.6^{* * *}$ & $25.6^{*}$ & -2.8 & $30.2^{*}$ & -6.5 & -1.5 & -8.1 \\
\hline \multirow[t]{3}{*}{7} & $17-9$ & 10.6 & -6.6 & 0.3 & 3.8 & 2.8 & 14.9 & 32.0 \\
\hline & $17-10$ & $24.7 * *$ & 13.4 & 10.8 & 14.6 & -18.5 & -15.3 & -1.5 \\
\hline & $17-12$ & 16.9 & -12.8 & 8.2 & -4.8 & -16.4 & 15.5 & 2.8 \\
\hline \multirow[t]{3}{*}{10} & $17-13$ & -6.5 & $32.8^{* *}$ & 6.6 & -1.7 & 26.5 & -33.3 & -8.9 \\
\hline & $17-14$ & $-23.1^{*}$ & -12.2 & -14.5 & -8.4 & 40.4 & 15.6 & 20.1 \\
\hline & $17-15$ & -13.6 & -4.0 & 1.5 & 4.0 & -15.6 & -17.5 & 4.1 \\
\hline \multirow[t]{3}{*}{12} & $17-16$ & 13.8 & 8.8 & -7.6 & 11.9 & 47.5 & -11.0 & 14.3 \\
\hline & $17-18$ & -4.7 & -0.4 & 12.3 & -3.6 & $69.4^{\circ 3}$ & -8.6 & $36.2^{\circ}$ \\
\hline & $17-19$ & $-34.0^{* * *}$ & -5.0 & 6.2 & 0.8 & $88.7^{\circ}$ & 13.2 & $83.4^{\circ}$ \\
\hline \multirow[t]{3}{*}{14} & $17-20$ & $-27.3^{* *}$ & -0.6 & -9.7 & -2.4 & $78.9^{\circ}$ & 2.7 & $92.2^{\circ}$ \\
\hline & $17-22$ & -4.3 & 10.1 & -8.5 & 8.7 & 43.3 & -27.1 & 27.0 \\
\hline & $17-24$ & $-24.8^{* *}$ & -16.2 & -4.4 & -2.9 & $76.2^{\circ}$ & -3.6 & $53.4^{\circ}$ \\
\hline \multirow[t]{3}{*}{17} & $17-25$ & -6.6 & 8.4 & 3.1 & 6.3 & 30.1 & -4.3 & $13 \cdot 9$ \\
\hline & $17-26$ & $-27.4^{*}$ & 4.1 & -16.2 & -12.0 & $78.8^{\circ}$ & 13.5 & $68.7^{\circ}$ \\
\hline & $17-29$ & -10.8 & 4.1 & -8.6 & -4.0 & 46.9 & 8.2 & 11.1 \\
\hline \multirow[t]{3}{*}{21} & $17-31$ & -18.7 & 10.0 & 12.1 & 3.1 & $72.3^{\circ}$ & $52.9^{\circ}$ & 48.8 \\
\hline & $17-33$ & -7.5 & 4.7 & 2.0 & -3.1 & 41.6 & 42.1 & 21.7 \\
\hline & $17-34$ & $-33.8 * * *$ & -11.3 & -4.3 & -5.8 & $80.0^{\circ}$ & $79.6^{\circ}$ & $57.4^{\circ}$ \\
\hline \multirow[t]{3}{*}{25} & $17-37$ & -8.7 & -17.2 & -7.8 & -1.4 & 36.9 & $63.1^{\circ}$ & $77.3^{\circ}$ \\
\hline & $17-38$ & 17.3 & 8.2 & 2.2 & 12.5 & -26.2 & 17.4 & 0.3 \\
\hline & $17-40$ & 6.8 & -2.9 & -3.5 & 1.0 & 20.3 & 23.6 & 42.5 \\
\hline \multirow[t]{3}{*}{28} & $17-41$ & -9.5 & -14.3 & -20.4 & -13.1 & $74.3^{\circ}$ & $83.9^{\circ}$ & $53.9^{\circ}$ \\
\hline & $17-43$ & 13.7 & -3.6 & -16.4 & 6.9 & 40.1 & 7.0 & 8.2 \\
\hline & $17-44$ & -14.1 & -6.8 & 14.3 & $28.8^{* * *}$ & 15.9 & $53.1^{\circ}$ & 23.2 \\
\hline \multirow[t]{3}{*}{31} & $17-46$ & 6.6 & $27.6^{* *}$ & -3.5 & 13.4 & 39.2 & -30.0 & 20.0 \\
\hline & $17-48$ & -11.3 & -10.3 & -4.5 & -6.1 & 67.8 & $58.3^{\circ}$ & $88.4^{\circ}$ \\
\hline & $17-49$ & -10.0 & -1.0 & -8.6 & 6.9 & 74.9 & 37.1 & $51.8^{\circ}$ \\
\hline \multirow[t]{3}{*}{35} & $17-50$ & -4.5 & -10.0 & -14.7 & -1.0 & $54.8^{\circ}$ & $67.8^{\circ}$ & $68.4^{\circ}$ \\
\hline & $17-52$ & 13.7 & 8.3 & 6.2 & 4.4 & 37.9 & 26.1 & 14.8 \\
\hline & $17-53$ & 5.9 & -3.2 & -21.0 & -6.5 & $59.5^{\circ}$ & 27.0 & 40.8 \\
\hline
\end{tabular}

1-3: See footnotes of Table I. 


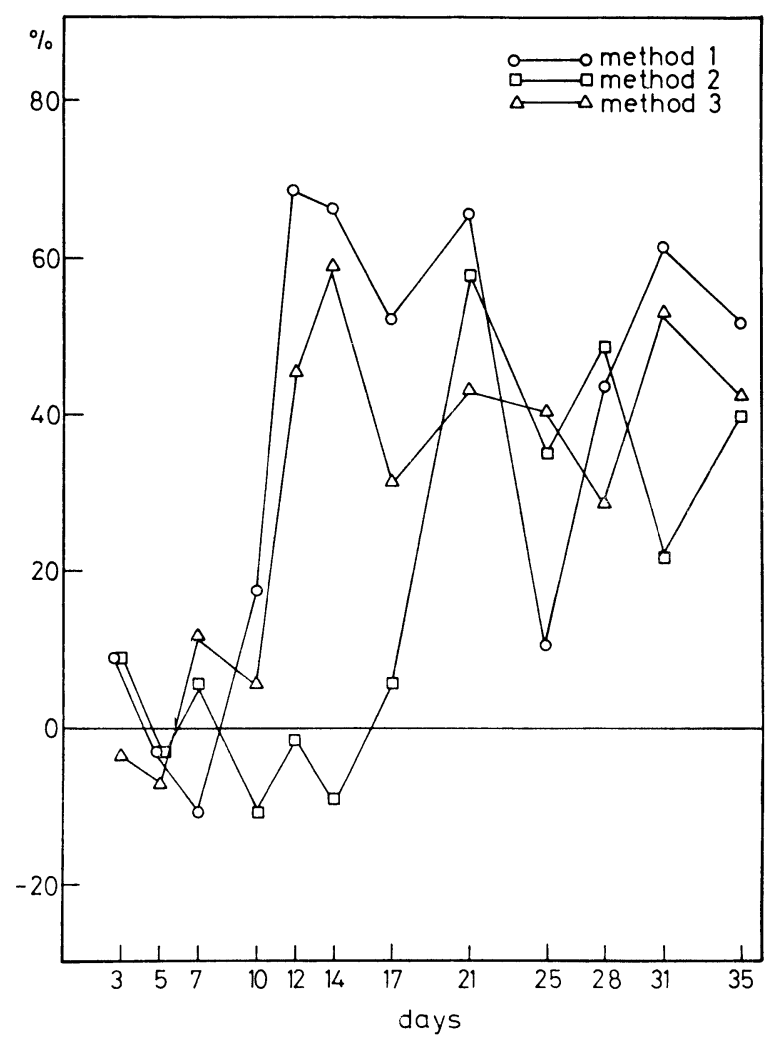

Fig. 6. Blocking activity of progressors detected by three methods. See footnotes of Fig. 2.

the spleen cells on growth of target cells instead of a cytotoxic effect.

Arming activity was detected 3-5 days p.i. corresponding to the appearance of cellular cytotoxicity (Fig. 5). This early arming activity was demonstrated by both methods 1 and 3, but not by method 2, suggesting involvement of an arming factor of a similar type as in regressors. In contrast to regressors, no arming activity was found after 7 days by any of the three methods.

Blocking activity was first detected at 12 days. Although there was relatively large variation in the results among serum samples, blocking activity seemed to hold a significantly high level from 12 days p.i. to the termination of the experiment. It is noteworthy that the blocking activity at 12-17 days p.i. was detected only by methods 1 and 3, and that most of the blocking activity after 21 days p.i. was demonstrated by all the three methods. The results indicate participation of blocking factors of different types in these two periods; the earlier one being effective on the effector-cell level, and the later one on both effector- and target-cell levels. 


\section{Discussion}

Time sequential studies were conducted on cellular cytotoxicity and humoral activities through the entire course of development of virus-induced primary tumors were conducted, comparing regressing tumors induced by a moderate dose of virus and progressing tumors induced by a large dose of virus. In regressors, cellular cytotoxicity exhibited a biphasic pattern; the first phase being observed as early as 3-5 days p.i., followed by an eclipse period for 7-10 days p.i. corresponding to the time of active tumor growth. The second phase of cytotoxic activity occurred 12 days p.i. A similar pattern of cellular cytotoxicity was reported by Lamon et al. (1972) in mice inoculated with murine sarcoma virus (MSV). They observed early appearance of cytotoxic spleen cells 2 days p.i., a minimum level of cellular cytotoxicity at the time of maximum tumor growth around 15 days p.i., and an increase of cellular cytotoxicity after tumor regression. Plata et al. (1974) also noticed a similar biphasic pattern of cellular cytotoxicity with an eclipse at the time of maximum tumor growth.

Early appearance of cellular cytotoxicity at 3-5 days p.i. when the tumor is not grossly detectable suggests earlier appearance of tumor-specific surface antigens or viral envelope antigens which can confer cytotoxic activity to the lymphoid cells. In fact, a small number of tumor cells could be demonstrated microscopically at this period (Yoshikawa et al., 1975).

Disappearance of cellular cytotoxicity during 7-12 days p.i. may imply the following mechanisms: (a) Since this period corresponds to the time of active tumor growth, cytotoxic lymphoid cells might be mobilized to the sites of tumor growth from the spleen. Histopathologically, infiltration of a large number of the lymphoid cells into the tumor tissues of regressors has been noted at this period (Yoshikawa et al., 1975). (b) During this latent period, high blocking activity was demonstrated and it is possible that this blocks the cytotoxic activity of existing cells. It has been suggested that the spleen cells consist of mixed populations of cytotoxic cells and blocking factor-producing cells, and that the latter blocks the cytotoxicity of the former in the in vitro assay system (Hayami et al., 1972). Similarly, the spleen cells obtained during the eclipse phase may consists of these mixed populations.

Kinetics of arming activity in regressors also showed a biphasic pattern as with cellular cytotoxicity. Arming activity was detected as early as 3 days p.i., the earliest sampling time in the present experiments. A very early appearance of arming activity at 24-48 $\mathrm{hr}$ p.i. has already been reported in MSV-induced tumors in mice by Pollack and Nelson (1974). It is interesting that the early arming activity in the present study reacts only with effector cells and the late one only with target cells in pre-incubation procedures. These results suggest involvement of arming factors of different types at the early and late stages of tumor development. It may be speculated simply that the early arming factor is of antigen nature and the late one is of antibody nature as suggested in antibody-dependent cell-mediated cytotoxicity (Perlmann et al., 1972). Characterization of these arming factors are 
now in progress.

The general time course of the arming activity corresponded well to that of the cellular cytotoxicity. Especially, there was a close correlation between early arming activity and early cellular cytotoxicity as revealed by the fact that only quails with positive early arming activity had the early cytotoxic spleen cells (Tables I and II). However, it may be still premature to conclude a causal correlation between the two activities.

Comparison of kinetics of immune functions between regressors and progressors is important in understanding the basic mechanisms of regression and progression of primary tumors. The present study confirmed our previous findings of the presence of cytotoxic spleen cells in regressors and their absence in progressors 3-5 weeks p.i. (Hayami et al., 1972). Histopathological examination also indicated a lack of cytotoxic lymphoid cells in progressors (Yoshikawa et al., 1975).

Although progressors showed early cellular cytotoxicity in a pattern like that of regressors, this activity disappeared 7 days p.i., and such re-appearance as observed in regressors did not occur. Instead, a phenomenon suggesting a stimulatory effect of spleen cells was noticed. A hypothesis of immunostimulation, that the lymphoid cells exert a stimulatory effect on tumor growth rather than an inhibitory one at an early stage of tumor development, was proposed by Prehn (1972), and has recently been studied in detail in mice inoculated with methylcholanthreneinduced tumors (Jeejeebhoy, 1974). A similar mechanism may be involved in the present tumor system. Since such stimulatory effect of the spleen cells was not so marked in regressors, it may be partly relevant to subsequent progression of tumors.

It has been suggested that blocking factor as well as cellular cytotoxicity are relevant to the outcome of tumor (Hellström and Hellström, 1973). Although blocking activity was demonstrated in both regressors and progressors in the present study, there was a marked difference in its kinetics; blocking activity was only transiently observed at the time of maximum tumor growth in regressors while it seemed to be rather consistently present in progressors after the tumor reached the maximum size. However, it is unknown whether this difference implies a causal correlation of the blocking factor to tumor progression, or is simply a consequence of it.

The blocking activity observed at the stage of active tumor growth in both regressors and progressors was effective only on the effector-cell level; that observed in progressors after the tumor reached the maximum size was on both effectorand target-cell levels. It may be suggested that the early blocking factor is antigen and the late one is antigen-antibody complex.

Involvement of tumor antigens as a blocking factor has been suggested by the detection of soluble tumor antigen in the sera of tumor-bearing animals (El Ridi and Bubenik, 1975; Poupon et al., 1974) and also by the demonstration of blocking activity in solubilized materials of tumor cells (Baldwin et al., 1973; Plata and Levy, 1974). The present study indicated that tumor antigen may be involved in not only blocking activity but also in early arming activity. It will be interesting to solve the question whether the same antigen at different concentrations or different antigens are involved in the blocking and arming activities. The pos- 
sibility that the early arming factor of antigen nature may be involved in an early defense mechanism should also be examined.

The target cells employed in the present study were virus-producing transformed cells which express on their surface both tumor-specific surface antigens (TSSA) and viral envelope antigens (Bauer et al., 1974). It remains to be clarified to which of these antigens the activities of cytotoxic spleen cells and humoral factors are directed.

\section{ACKNowledgement}

We thank Drs. A. Fukuda and F. Kobune for their technical help and discussions and Drs. H. Bauer and R. Friis for finishing this manuscript.

\section{REFERENCES}

Baldwin, R. W., Price, M. R., ANd Robins, R. A. (1973): Inhibition of hepatoma-immune lymph-node cell cytotoxicity by tumor-bearer serum, and solubilized hepatoma antigens. Intern. J. Cancer, 11, 527-535.

Bauer, H., Kurth, R., Rohrschneider, L., Pauli, G., R. R., and Gelderblom, H. (1974): The role of cell surface changes in RNA tumor virus-transformed cells. Cold Spring Harbor, XXXIX, 1181-1185.

EL RIDI, AND Bubenik, J. (1975): Tumor-associated transplantation antigen in sera of rats with large RSV-induced sarcomas. Intern. J. Cancer, 16, 83-90.

Hayami, M., Hellström, K. E., And Yamanouchi, K. (1972): Cell-mediated destruction of Rous sarcomas in Japanese quails. Intern. J. Cancer, 10, 507-517.

Hayami, M., Hellström, I., and Hellström, K. E. (1973): Serum effects on cell-mediated destruction of Rous sarcomas. Intern. J. Cancer, 12, 667-688.

Hayami, M., Hellström, I., Hellström, K. E., and Lannin, D. R. (1974): Further studies on the ability of regressor sera to block cell-mediated destruction of Rous sarcomas. Intern. J. Cancer, 13, 43-53.

Hellström, K. E. AND Hellström, I. (1970): Colony inhibition studies on blocking and nonblocking serum effect on cellular immunity to Moloney sarcomas. Intern. J. Cancer, 5, 195-201.

Hellström, K. E. ANd Hellström, I. (1973): Lymphocyte mediated cytotoxicity and blocking serum activity to tumor antigens. Advan. Immunol., 18, 209-277.

JEEJEEBHOY, H. (1974): Stimulation of tumor growth by the immune response. Intern. J. Cancer, $13,665-678$.

Lamon, E. W., Skurzak, H. M., ANd Klein, E. (1972): The lymphocyte response to a primary viral neoplasm (MSV) through its entire course in BALB/c mice. Intern. J. Cancer, 10, 581-588.

Perlmann, P., Perlmann, H., and Wigzell, H. (1972): Lymphocyte mediated cytotoxicity in vitro. Induction and inhibition by humoral antibody and nature of effector cells. Transplant. Rev., 13, 91-114.

Plata, F., Gomard, E., Leclerc, J. C., And Levy, J. P. (1974): Comparative in vitro studies on effector cell diversity in the cellular immune response to murine sarcoma virus (MSV)-induced tumors in mice. J. Immunol., 112, 1477-1487.

Plata, F. ANd Levy, J. P. (1974): Blocking of syngeneic effector T cells by soluble tumor antigens. Nature, 294, 271-274.

Pollack, S., Heppner, G., Bbawn, R. J., and Nelson, K. (1972): Specific killing of tumor cells in vitro in the presence of normal lymphoid cells and sera from hosts immune to the tumor antigens. Intern. J. Cancer, 9, 316-323.

Pollack, S. ANd Nelson, K. (1974): Early appearance of a lymphoid arming factor and cytotoxic lymph-node cells after tumor induction. Intern. J. Cancer, 14, 522-529.

Poupon, M. F., Lespinats, G., AND Kolb, J. P. (1974): Blocking effect of the migration-inhibition 
reaction by sera from immunized syngeneic mice and by sera from plasmacytoma-bearing $\mathrm{BALB} / \mathrm{c}$ mice. Detection of free, circulating tumor antigen. J. Nat. Cancer Inst., 52, 11271134.

Prehn, R. T. (1972): The immune reaction as a stimulator of tumor growth. Science, 176, $170-171$.

Takasugi, M. AND Klein, E. (1970): A microassay for cell-mediated immunity. Transplantation, 9, 219-227.

Yamanouchi, K., Hayami, M., Fukuda, A., And Kobune, F. (1968): Tumor development and induction of resistance by Rous sarcoma virus in Japanese quail. Japan. J. Med. Sci. Biol., $21,393-404$.

Yoshikawa, Y., Yamanouchi, K., Takahashi, R., and Fujiwara, K. (1975): Histopathological observations of spontaneous regression of Rous sarcomas in Japanese quails. Japan. J. Med. Sci. Biol., 28, 117-126. 